UDC 339.564:330.322(669)

JEL Classification: H54; N5; 013; 018; Q13; Q14; Q17

DOI: https://doi.org/10.32317/2221-1055.202005087

\author{
Onyinye I. Anthony-Orji, Phd \\ Anthony Orji, Phd \\ Jonathan E. Ogbuabor, Phd \\ Precious Ezealigo
}

\title{
Empirical analysis of agricultural and non-agricultural exports'impact on infrastructural investment in Nigeria
}

The purpose of the article is to estimate the impact of agricultural and non-agricultural exports on infrastructural investment in Nigeria.

Research methods. In the research process, the following scientific methods have been used: The study adopted the Autoregressive Distributed Lag - Unrestricted Error Correction Model (ARDL-UECM) to estimate the impact of agricultural and non-agricultural exports on infrastructural investment in Nigeria. The ARDL model was estimated using Eviews 9.

Research results. The regression results showed that agricultural export has a significant positive relationship with infrastructural investment while non-agricultural export was found to have an insignificant relationship with the dependent variable.

Scientific novelty. This paper adds to the body of literature on this subject for the economy of Nigeria and other related economies because this is the first paper investigating the joint impact of agricultural and non-agricultural exports on infrastructural investment in Nigeria. The study makes some innovative findings and recommendations that the government should invest more in mechanised farming and as well ensure that the agricultural sector is made more viable and productive since the country has a comparative advantage in agriculture.

Practical significance. Practically, this study is significant in many ways. Following the empirical results it has become practically clear that agricultural produce should not only be exported in its primary form but there should be value added in order to make Nigeria's exports more competitive in the international market. Income generated from agricultural and non-agricultural exports by government should be properly accounted for and invested into more capital projects to boost the level of infrastructure in the Nigerian economy. Tabl.: 4. Figs.: 2. Refs.: 15.

Keywords: analysis; agriculture; agriculture and non-agriculture exports; infrastructure; investment.

Onyinye I. Anthony-Orji - Phd, Department of Economics, University of Nigeria, Nsukka (Postal code 410001 Nsukka, Enugu, Nigeria)

E-mail: onyinye.anthony-orji@unn.edu.ng

ORCID iD http://orcid.org/0000-0002-0603-7264

Anthony Orji - Phd, Department of Economics, University of Nigeria, Nsukka (Postal code 410001 Nsukka, Enugu, Nigeria) (Corresponding Author)

E-mail: anthony.orji@unn.edu.ng

ORCID iD http://orcid.org/0000-0003-4032-7051

Jonathan E. Ogbuabor - Phd, Department of Economics, University of Nigeria, Nsukka (Postal code 410001 Nsukka, Enugu, Nigeria)

E-mail: jonathan.ogbuabor@unn.edu.ng

ORCID iD http: //orcid.org/0000-0002-0162-0303

Precious Ezealigo - University of Nigeria, Nsukka (Postal code 410001 Nsukka, Enugu, Nigeria)

E-mail: precious.ezealigo.189171@unn.edu.ng

Scientific problem. Nigeria, with a population of about 200 million people, a Gross Domestic Product of US\$398 billion and a per capita income of about US\$2,028.18, abundant natural resources, over 700,000 square kilome-

(c) Onyinye I. Anthony-Orji, Anthony Orji, Jonathan E. Ogbuabor, Precious Ezealigo, 2020 tres of arable land and large deposits of untapped minerals, is, seen by many scholars and observers as a Nation that is yet to fully harness her potential and is yet to attain better heights of development, especially in infrastructure and in core and real sectors of the economy, as well as better GDP per capita (CBN, 2019). Being a largely import-dependent 
country, Nigeria's currency encounters a downward pressure, thus making imports cheaper than exports. The government's revenue (of which oil revenues previously contributed about $60-75 \%$ ) has also declined hugely due to the crash in oil prices from a high of US\$115/barrel in August 2014 to almost US\$30/barrel in 2020 owing to the global lockdown occasioned by the Covid-19 pandemic (World Bank, 2020). The decline in government's revenue was largely due to two reasons: the overdependence on oil revenues, and limited investments in infrastructure when there was a boom in oil prices, thus, creating significant pressures on the country's currency. This calls for the diversification of the economy, more particularly exports.

Infrastructure in Nigeria has taken a slow pace over the years despite the revenues gotten from oil before the crash in oil prices. It is imperative to note that with Nigeria's growing population and level of economic growth, there is desperate need for infrastructural investment in Nigeria. Investing in infrastructure would increase employment, increase capital inflows, increase economic growth, reduce urban/rural migration, increase export, increase balance of payments, reduce mortality rate, spur growth in the real sectors, advance the existing technology, and will indirectly, but more importantly, increase per capita income. Infrastructure investment is needed in different core and social sectors such as energy, transport, and urban development/real estate, healthcare, water, agriculture, waste management, and Information Communication Technology (ICT).

The World Economic Forum estimates that every dollar spent on capital projects (in utilities, energy, transport, waste management, flood, defence, and telecommunications) generates an economic return of $5 \%$ to $25 \%$. That multiplier effect accounts for the rapid economic growth of emerging markets that have made infrastructure spending a priority. This readily translates to opportunities for sponsors or investors that are keen on developing infrastructure projects in their local economies (Abadie, 2014).

Significant gaps exist in both rural and urban areas across Nigeria ranging from availability of basic infrastructure such as housing, healthcare, water, and waste management, to other enabler infrastructure like ICT, hospitality, and industrial / commercial real estate.
Hence, the dire need of investment in infrastructure by both the private and public sectors of the country (World Bank, 2016).

Nigeria, being an import-dependent and a monolithic-export country has its exportspotential sectors such as agricultural and manufacturing sectors handicapped, producing far less than their potential. The crash in oil prices has greatly affected the country's economy and the exchange rate system, thus, leading to the fall in the demand of the naira in the international market. Also, the adoption of an import-restrictive policy (ban on certain import goods) led to increased cost of production and, as well, increased prices for goods and services (cost-push inflation). In 2015, the manufacturing sector and agricultural sector's contribution to the GDP were about $9.53 \%$ and $20.86 \%$ respectively, while oil rents shockingly contributed 3.03\% (NBS, 2017). The situation has even worsened during the current surge of the global pandemic known as COVID-19, where oil price has reduced to almost negative values according to OPEC (2020).

Analysis of recent research and publications. This notwithstanding, Nigeria has made some efforts recently on how to revamp the economy through the Economic Recovery and Growth Plan (ERGP). However, despite the effort of the government in revamping agricultural and non-agricultural exports, their contributions to infrastructural development in Nigeria remain an empirical question. Empirically no study has been conducted in Nigeria on Agricultural Exports and Infrastructural Investment but studies such as Gilbert, Linyong, and Divine (2013), ljirshar (2015) and Verter and Becvárová (2016), among others have been done to investigate the relationship between agricultural export and economic growth in different economies. Specifically, ljirshar (2015) carried out an empirical analysis of agricultural export and economic growth in Nigeria using data that spanned from 1970 to 2012. He employed the Error Correction Model (ECM) in his analysis and found out that Agricultural export contributed positively to the growth of the $\mathrm{Ni}$ ів добробуту дозволяє зауважити високий рі and Verra (2016) investigated the impact of agricultural exports on economic growth in Nigeria using OLS regression, Granger causality, and other methodologies. Both the OLS regression and Granger causality results show that agricultural exports is directly related to economic growth, while agricultural degree of openness 
is inversely related to economic growth in $\mathrm{Ni}$ geria. Other studies that found similar results include; Hyunsoo, K. (2015) and Oluwatoyese et al (2016). Other recent studies in this area include Orji, Ogbuabor, Anthony-Orji, and Alisigwe (2020) on Agricultural Financing and Agricultural Output Growth in Developing Economies; Orji, Ogbuabor, Okeke, AnthonyOrji (2019) on Exchange Rate Movements and the Agricultural Sector in Nigeria; and Orji, Ogbuabor, and Umesiobi (2014) on Agricultural Outputs, Food Security and Economic Development in Africa. These are important studies but their focus is quite different from this current study.

Since no study has been conducted to determine the impact of agricultural and nonagricultural export on infrastructure investment in Nigeria, this study becomes very relevant at this critical time in the history of $\mathrm{Ni}$ geria. This is the focus and value addition of this paper.

The purpose of the article is therefore, to estimate the impact of agricultural and nonagricultural exports on infrastructural investment in Nigeria.

The rest of the paper is structured as follows; Section 3 dwells on the methodology.
The results are presented and discussed in section 4 , while section 5 concludes the study and makes some vital policy recommendations.

Research methodology. To capture the objective of this study, we develop a regression model that shows the impact of agricultural and non-agricultural exports on infrastructural investment in Nigeria, 1980-2015. The dependent variable is infrastructural investment; however, Road Contribution to GDP (ROCY) will serve as a proxy to infrastructural investment, while the explanatory variables include Agricultural export (AGEX), NonAgricultural export (NAGEX), Labour Force Participation Rate (LFPR), Exchange Rate (EXRT), and Inflation Rate (INFL). The study adopts the modelling technique of Autoregressive Distributed Lag (ARDL) Model proposed by Pesaran (2001).

Modelling the impact of agricultural and non-agricultural exports on infrastructural investment we specify the functional form of the relationship as:

ROCY = F (AGEX, NAGEX, LFPR, EXRT, INFL)

For econometric estimation, we re-specify the Autoregressive Distributed Lag (ARDL) Model as:

$\Delta \operatorname{lnROCY}_{\mathrm{t}}=\beta_{0}+\sum_{i=1}^{\rho} \beta_{1} \Delta \operatorname{lnROCY}_{\mathrm{t}-i}+\sum_{i=0}^{\rho} \beta_{2} \Delta \ln \mathrm{AGEX}_{\mathrm{t}-i}+\sum_{i=1}^{\rho} \beta_{3} \Delta \operatorname{lnNAGEX} \mathrm{t}_{\mathrm{t}-i}+\sum_{i=1}^{\rho} \beta_{4} \Delta \mathrm{LFPR}_{\mathrm{t}-i}+\sum_{i=1}^{\rho} \beta_{5} \Delta \mathrm{EXRT}_{\mathrm{t}-i}$ $+\sum_{i=1}^{\rho} \beta_{6} \Delta \mathrm{INFL}_{\mathrm{t}-i}+\alpha_{1} \operatorname{lnROCY} \mathrm{Y}_{\mathrm{t}-1}+\alpha_{2} \operatorname{lnAGEX}_{\mathrm{t}-1}+\alpha_{3} \operatorname{lnNAGEX} \mathrm{t}_{\mathrm{t}-1}+\alpha_{4} \mathrm{LFPR}_{\mathrm{t}-1}+\alpha_{5} \mathrm{EXRT}_{\mathrm{t}-1}+\alpha_{6} \mathrm{INFL}_{\mathrm{t}-1}+\mu_{\mathrm{t}}$

Where,

ROCY = Road Contribution to GDP (Proxy for infrastructure investment); $A G E X=$ Agricultural export

NAGEX = Non-Agricultural export; LFPR $=$ Labour Force Participation Rate; EXRT= Exchange Rate

INFL= Inflation Rate; $\Delta$ is the first difference operator, and $\mu$ is the random error term

\section{Long run elasticities}

If there is a long run relationship between agricultural export, non-agricultural export, labour force participation rate, exchange rate, interest rate and inflation, the long run elasticities can be estimated using the equation specified below:

$$
\begin{aligned}
& \ln \operatorname{ROCY}_{\mathrm{t}}=\gamma_{0}+\sum_{i=0}^{k} \gamma_{1} \operatorname{lnROC\mathrm {CP}_{\mathrm {t}-1}}+\sum_{i=0}^{k} \gamma_{2} \ln \mathrm{AGEX}_{\mathrm{t}-1}+\sum_{i=0}^{k} \gamma_{3} \ln \mathrm{NAGEX}_{\mathrm{t}-1}+\sum_{i=0}^{k} \gamma_{4} \mathrm{LFPR}_{\mathrm{t}-1}+ \\
& \sum_{i=0}^{k} \gamma_{s} \text { EXRT }_{t-1}+\sum_{i=0}^{k} \gamma_{6} \operatorname{INFL}_{t-1}+\mu_{t}
\end{aligned}
$$

Equation (3) above represents the long run relationship. However, for policy reasons, it is necessary to estimate the short run equation

to capture the speed of adjustment. This is shown below in equation (4):

Short run elasticities

$$
\begin{aligned}
& \Delta \operatorname{lnROCY}_{k}=\beta_{0}+\sum_{i=1}^{k} \beta_{1} \Delta \operatorname{lnROCY_{\mathrm {t}-1}}+\sum_{i=0}^{k} \beta_{i} \Delta \ln A G E X_{\mathrm{t}-1}+\sum_{i=0}^{k} \beta_{3} \Delta \operatorname{lnNAGEX} \mathrm{t}_{\mathrm{t}-1}+\sum_{i=0}^{k} \beta_{4} \Delta \mathrm{LFPR}_{\mathrm{t}-1}+\sum_{i=0}^{k} \beta_{5} \Delta \mathrm{EXRT}_{\mathrm{t}-1} \\
& +\sum_{i=0} \beta_{6} \Delta \mathrm{INFL}_{\mathrm{t}-1}+\mathrm{aECM}_{\mathrm{t}-1}+\mu_{\mathrm{t}}
\end{aligned}
$$


Where,

a measures the speed of adjustment to obtain long run equilibrium, and
$E C M_{t-1}$ is the error correction term.

Research results

1. Stationarity test

Table 1. Result for stationarity test

\begin{tabular}{|c|c|c|c|c|c|}
\hline \multirow{2}{*}{ VARIABLE } & \multicolumn{2}{|c|}{ AT LEVELS } & \multicolumn{2}{c|}{ AFTER FIRST DIFFERENCE } & \multirow{2}{*}{ ORDER OF } \\
\cline { 2 - 5 } & $\begin{array}{c}\text { ADF TEST } \\
\text { STATISTIC }\end{array}$ & $\begin{array}{c}\text { ADF MACKINNON } \\
\text { CRITICAL VALUE AT 5\% }\end{array}$ & $\begin{array}{c}\text { ADF TEST } \\
\text { STATISTIC }\end{array}$ & $\begin{array}{c}\text { ADF MACKINNON } \\
\text { CRITICAL VALUE AT 5\% }\end{array}$ & INTEGRATION \\
\hline InROCY & 0.307157 & -2.948404 & -5.871723 & $-2.951125^{* *}$ & $\mathrm{I}(1)$ \\
\hline InAGEX & -2.457580 & -2.948404 & -8.378595 & $-2.951125^{* *}$ & $\mathrm{I}(1)$ \\
\hline InNAGEX & -3.035870 & $-2.948404^{* *}$ & -7.714812 & 2.951125 & $\mathrm{I}(0)$ \\
\hline EXRT & 0.397537 & -2.948404 & -5.275958 & $-2.951125^{* *}$ & $\mathrm{I}(1)$ \\
\hline LFPR & -1.747388 & -2.954021 & -2.488705 & $-1.951000^{* *}$ & $\mathrm{I}(1)$ \\
\hline INFL & -2.832587 & -2.948404 & -5.515111 & $-2.951125^{* *}$ & $\mathrm{I}(1)$ \\
\hline
\end{tabular}

${ }^{* *}$ indicates that the variable became stationary at $5 \%$ level of significance.

Source: Authors' computation from Eviews 9 output

In summary, from the table above, we can deduce that all the variables in model one were stationary after first difference except InNAGEX which was stationary at level form.

\section{Cointegration test}

This test helps to determine whether a long run relationship exists among the dependent and independent variables of the model. This work employed the ARDL Bounds Test in order to determine if a long run relationship exists among the variables.

Table 2. Result for cointegration test

\begin{tabular}{|c|c|c|}
\hline \multirow{2}{*}{ F-STATISTIC } & \multicolumn{2}{|c|}{ CRITICAL VALUE BOUNDS AT 5\% } \\
\cline { 2 - 3 } & LOWER BOUND I(0) & UPPER BOUND I(1) \\
\hline $7.394500^{* *}$ & 2.62 & 3.79 \\
\hline
\end{tabular}

${ }^{* *}$ indicates the existence of a cointegrating relationship at $5 \%$ level of significance.

Source: Authors' computation from Eviews 9 output

Table 2 above shows that the F-statistic is 7.394500. With $k=5$, the critical values for lower and upper bounds are 2.62 and 3.79 respectively at $5 \%$ level of significance. Since the value of the F-statistic (7.394500) lies above the upper bound (3.79), we reject the null hypothesis and conclude that there is a long run relationship existing among the variables.
The result shows the presence of cointegration and therefore a long run relationship between the dependent variable (road contribution to GDP) and the explanatory variables (agricultural export, non-agricultural export, exchange rate, labour force participation rate and inflation rate).

3. Presentation and analysis of ARDLUECM result

Table 3. Result for long run relationship dependent variable: InROCY

\begin{tabular}{|c|c|c|c|c|}
\hline VARIABLE & COEFFICIENT & STD. ERROR & t-STATISTIC & PROB. \\
\hline InAGEX & 0.111650 & 0.025815 & 4.324986 & 0.0008 \\
\hline InNAGEX & -0.002785 & 0.023469 & -0.118651 & 0.9074 \\
\hline EXRT & 0.004854 & 0.001128 & 4.302017 & 0.0009 \\
\hline LFPR & -0.191131 & 0.058919 & -3.243951 & 0.0064 \\
\hline INFL & -0.003963 & 0.003851 & -1.028891 & 0.3223 \\
\hline CONSTANT & 16.314940 & 3.515717 & 4.640573 & 0.0005 \\
\hline $\begin{array}{l}\text { R-SQUARED }=0.995283 \\
\text { ADJUSTED R-SQUARED }=0.988389\end{array}$ & F-STATISTIC = 144.3736 \\
\hline DURBIN-WATSON $=2.394463$ & PROB F-STATISTIC $=0.000000$ \\
\hline
\end{tabular}

Source: Authors' computation from Eviews 9 output

\section{Discussion}

The coefficient of InAGEX has a positive sign. This indicates that a positive and direct relationship exists between road contribution to GDP and agricultural export. With the coef- ficient of 0.111650 , a percentage increase in agricultural export will, on the average, lead to about $0.11 \%$ increase in infrastructural investment, holding other variables constant. This conforms to the a priori expectation 
which states that the higher the level of exports, the greater the investment in infrastructure. This also conforms to the work of Jouanjean (2013) who found out that agricultural trade has a positive relationship with infrastructural investment. Thus, increasing agricultural export composition will likely increase infrastructural investment in Nigeria by about $0.11 \%$. Thus, the government should look into growing, improving and enhancing the agricultural sector in order for the sector to contribute substantially to exports which would, in the long run, lead to an increase in infrastructural investment.

NON-AGRICULTURAL EXPORT (InNAGEX): This variable has a negative sign, indicating a negative or indirect relationship between nonagricultural export and infrastructural investment. With a coefficient of -0.002785 , a one percent $(1 \%)$ increase in non-agricultural export holding other variables constant will, on the average, lead to about a $0.0028 \%$ decrease in infrastructural investment. This does not conform to a priori expectation which states that increase in the level of exports has a positive relationship with a nation's infrastructural development, and as such is not in accordance with the findings from the works of Jouanjean (2013) and Ismail and Mahyideen (2015) who found out that trade and infrastructure development are positively related. The reason for the negative coefficient could be said to be as a result of lack of diversity in exports (monotony of exports), as the country depends largely on the export of crude oil which is very volatile and has a very competitive market.

EXCHANGE RATE (EXRT): The result in table 3.3 shows that the exchange rate has a positive relationship with infrastructural investment. Thus, with a coefficient of 0.004854 , a unit increase in exchange rate will, on the average, lead to $0.0049 \%$ increase in infrastructural investment, holding other variables constant. This implies that a one naira increase in the exchange rate will increase infrastructural investment by $0.0049 \%$. This conforms to $a$ priori expectation since an increase in exchange rate implies an appreciation in the rate of exchange. Hence, investors tend to gain confidence in the country's currency seeing that the currency competes favourably in the international market. Thus, infrastructural development, through foreign direct investment increases leading to increase in the nation's balance of payment and cash inflows which could be invested in the development of the nation's infrastructure.

LABOUR FORCE PARTICIPATION RATE (LFPR): The coefficient of LFPR is -0.191131 . This shows that a negative and indirect relationship exists between infrastructural investment and labour force participation rate. Thus, a unit increase in labour force participation rate will, on the average, decrease infrastructural investment by $0.19 \%$, holding other variables constant. This does not conform to a priori expectation. It is expected that labour force participation rate would be positively related with infrastructural investment, in that the number of unemployed individuals is reduced implying that a greater number of those who are willing and able to work are able to find work. Hence, having majority of the independent or working population (those under the age bracket of 18 to 64) being employed implies that the government revenue would increase (through taxes) given a higher rate of labour force participation. It is expected that the percentage or proportion allocated to infrastructural development would also increase. However, with high rate of unemployment, high level of corruption, embezzlement, looting and improper use of government funds, as well as high level of tax evasion prevalent in Nigeria, the revenue generated by the government is reduced (suboptimal) and insufficient for carrying out government projects which includes infrastructure development. Hence, the existence of a negative relationship between infrastructural investment and labour force participation rate in Nigeria.

INFLATION RATE (INFL): Inflation rate, from the table above, is seen to have a negative relationship with infrastructural investment. With a coefficient of -0.003963 , a unit increase in inflation rate will, on the average, reduce infrastructural investment by $0.004 \%$, holding other variables constant. This conforms to a priori expectation. It is expected that inflation relates negatively with investments because as inflation rate increases, the cost of investment increases in nominal terms, thereby, reducing the rate or level of investment. In lieu of this, a unit increase in inflation rate will also, most likely, reduce infrastructural investment.

The coefficient of determination, $R^{2}$ is the measure of the proportion of the variations in 
the dependent variable that are explained by the explanatory variables. It shows to what extent the variations in the dependent variable are explained by the independent variables while the Adjusted $R^{2}$ gives the value of the $R^{2}$ after it has been adjusted for the degrees of freedom for the sum of squares. In this case, it measures how the variations in the infrastructural investment (ROCY) are explained by the independent variables which are agricultural export (AGEX), nonagricultural export (NAGEX), Exchange rate
(EXRT), labour force participation rate (LFPR) and inflation rate (INFL). The value of $R^{2}$ is 0.995283 meaning that the variations in infrastructural investment are explained by independent variables up to $99.5 \%$. The adjusted $\mathrm{R}^{2}$ helps to check whether the R-squared overestimated the success of the model. Since its value $(0.988389)$ is not so different from the $\mathrm{R}^{2}$, we can then conclude that the success of the model is not over-estimated. This signifies that the model is a good fit.

\section{ARDL-UECM short run relationship}

Table 4. Result for short run relationship

\begin{tabular}{|c|c|c|c|c|}
\hline VARIABLE & COEFFICIENT & STD. ERROR & T-STATISTIC & PROB. \\
\hline$\Delta$ LN(ROCY(-1)) & 0.219210 & 0.139288 & 1.573796 & 0.1395 \\
\hline$\Delta$ LN(AGEX) & 0.040018 & 0.013635 & 2.934983 & 0.0116 \\
\hline$\Delta$ LN(AGEX(-1)) & -0.080244 & 0.016258 & -4.935646 & 0.0003 \\
\hline$\Delta$ LN(NAGEX) & 0.011581 & 0.013318 & 0.869618 & 0.4003 \\
\hline$\Delta$ LN(NAGEX(-1)) & 0.016251 & 0.011967 & 1.358037 & 0.1976 \\
\hline$\Delta$ LN(NAGEX(-2)) & 0.017604 & 0.009413 & 1.870238 & 0.0841 \\
\hline$\Delta$ (EXRT) & 0.002435 & 0.001463 & 1.664134 & 0.1200 \\
\hline$\Delta$ (EXRT(-1)) & 0.000532 & 0.001326 & 0.401300 & 0.6947 \\
\hline$\Delta$ (EXRT(-2)) & -0.002872 & 0.001210 & -2.373246 & 0.0337 \\
\hline$\Delta$ (LFPR) & 0.197300 & 0.185580 & 1.063155 & 0.3071 \\
\hline$\Delta$ (INFL) & -0.000318 & 0.001335 & -0.238360 & 0.8153 \\
\hline$\Delta$ (INFL(-1)) & -0.000830 & 0.001576 & -0.526224 & 0.6076 \\
\hline$\Delta$ (INFL(-2)) & 0.004111 & 0.001743 & 2.359292 & 0.0346 \\
\hline ECM (-1) & -0.906129 & 0.186548 & -4.857356 & 0.0003 \\
\hline
\end{tabular}

Source: Authors' computation from Eviews 9 output

The signs of the short run dynamic interactions are consistent with those of the long run relationship, except non-agricultural export and labour force participation rate which have negative signs in the short run as opposed to the positive sign they have in the long run.

The error correction term is negative and statistically significant which reconfirms the presence of a long run equilibrium relationship among import and expenditure components. $E C M_{t-1}$ measures the speed at which infrastructural investment adjusts to changes in the explanatory variables before converging to its equilibrium level. The estimated coefficient of the error correction term indicates the speed of adjustment among the variables within a year. With a coefficient of -0.906129 , it means that approximately $91 \%$ of disequilib- rium from the previous year will converge back to the long run equilibrium in the current year. In other words, the model will correct $91 \%$ of the system disequilibrium within a year. The estimated error correction coefficient $(-0.906129)$ implies a very high speed of adjustment and has a probability value of 0.0003 implying that it is highly significant at $5 \%$ level of significance $(p<0.05)$.

\section{Cusum and Cusum of Squares}

The cumulative sum (CUSUM) and cumulative sum of square (CUSUMQ) plots from a recursive estimation of the model is shown in Figures 1 and 2, respectively. This indicates stability in the coefficients over the sample period as the plot of the CUSUM and CUSUMSQ statistic fall inside the critical bands of the $5 \%$ confidence interval of parameter stability. 


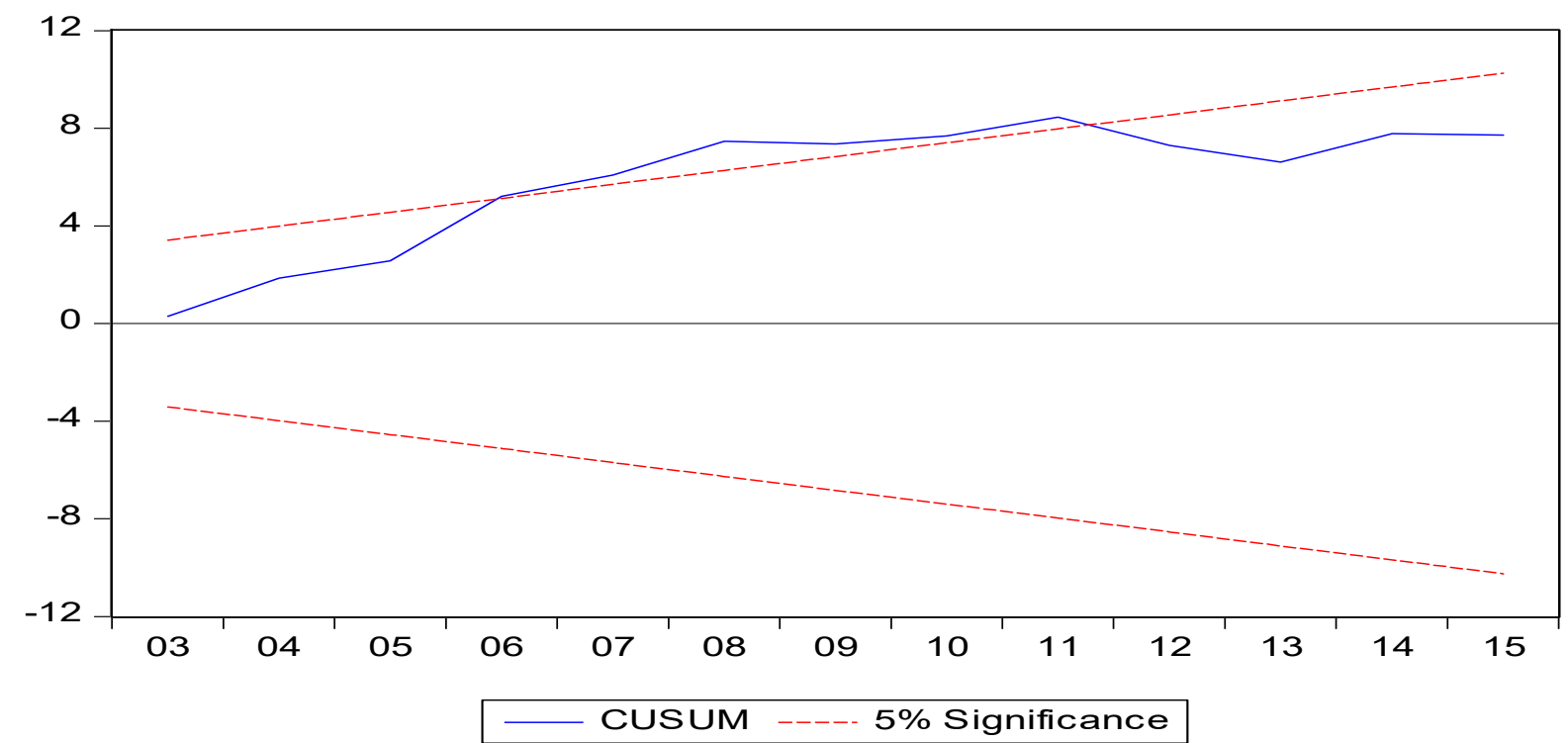

Figure 1. Cusum plot

${ }^{*}$ The straight lines are critical bounds at $5 \%$ level of significance.

Source: Authors' computation from Eviews 9 output

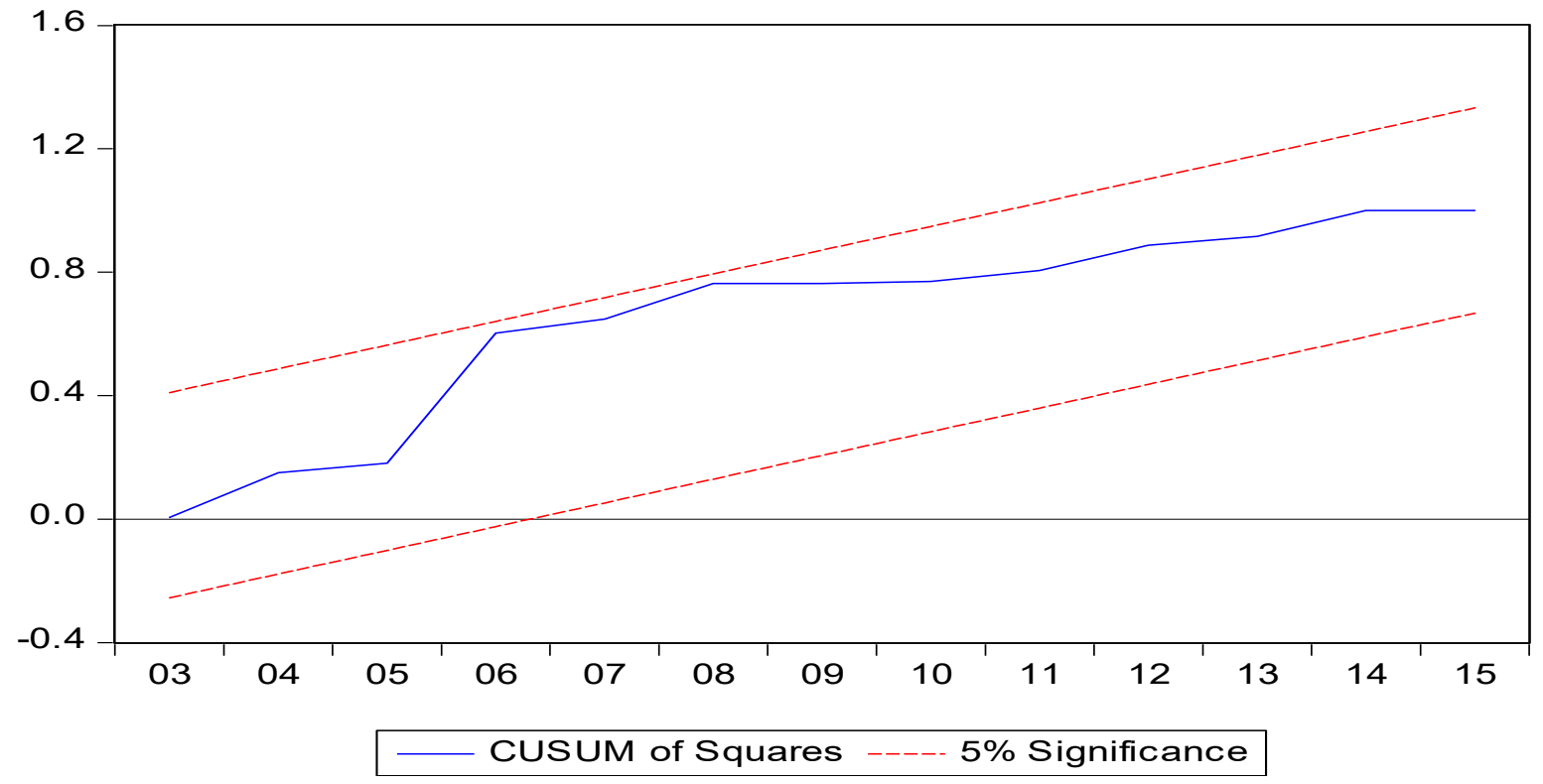

Figure 2. Cusum of squares plot

*The straight lines are critical bounds at $5 \%$ level of significance

Source: Authors' computation from Eviews 9 output

This indicates stability in the coefficients over the sample period as the plot of the CUSUM and CUSUM of Squares statistic fall inside the critical bound of the $5 \%$ confidence interval of parameter stability. Although the CUSUM graph exceeded the critical bound, the model appears to be correctly specified and generally stable as the CUSUM of squares did not exceeded the bounds of the $5 \%$ level of significance.

2. Policy recommendations and conclusions

Empirical evidence from this study shows that infrastructural investment is crucial to the growth and development of any economy. Infrastructural investment should therefore be consciously spurred by calculated economic decisions and policies. Investing in both hard infrastructures (electricity, water, transportation, communication, et cetera) and soft infrastructures (business and regulatory environments) spurs great positive economic effects such as attracting investors, increasing the balance of payments through increased cash inflows, improving trade and other economic benefits.

In the light of this insight, the government should ensure the diversification of exports. 
From the results of this research, we notice that while agricultural export (InAGEX) was significant and conformed to a priori expectations, non-agricultural export (InNAGEX) was found to be insignificant and did not conform to a priori expectations. This could be due to an effect known as the Dutch disease whereby the growth and development of a sector in an economy negatively affects the economy. In the case of Nigeria, the discovery of oil and the growth of the oil sector led to a sharp increase in the exportation of crude oil, hence leading to high inflow of foreign currencies. The foreign currency inflows led to the depreciation of the local currency, thus, making other primary product export from Nigeria less competitive at the export market. This effect leads to higher levels of cheap imports and can lead to deindustrialisation, as industries move to cheaper locations where they can compete favourably as well as export their products. Hence, the Nigerian government is expected to build and invest in soft and hard infrastructures that would help to facilitate diversity in exports in order to experience a significant impact from exports.

Again, there is need for the government to also ensure the revival of the agricultural sector and most importantly, the export of agricultural products or commodities. Given that the variable, agricultural export was significant, it implies that increasing the level of exports from the agricultural sector will have a significant impact on the economy in terms of higher infrastructural investment. The government should also ensure the appropriate use of revenue gotten from exports. They should curtail wastage and should not engage in irrelevant and extravagant expenditures. The government should ensure that there is suitable and favourable environment for businesses to thrive, given that this is one of their basic or fundamental roles. The existence of a favourable environment attracts investors as well as foreign direct investments. It should be noted that foreign direct investment could also contribute to infrastructural investment and development. They should also perform their regulatory roles, especially in terms of regulating inflation. Since cost-push inflation affects the economy negatively, the government should ensure that its activities and decisions do not lead to cost-push inflation. Also, the government should effectively regulate demand-pull inflation. Furthermore, in order to increase the profitability of agricultural export, most of the agricultural products should not just be exported in their crude or raw form; rather, there should be value addition to the products before they are exported (e.g. intermediate agricultural products). The government should also invest in mechanised farming and make loans accessible to farmers at affordable interest rates. More so, the government should also enact or make policies that ensure greater labour force participation. This variable was found to be statistically significant, thus implying that ensuring that those who are willing and able to work are employed as well as ensuring that those who are employed are productive would indeed have a good impact on the Nigerian economy. Finally, the government should also ensure that the exchange rate is relatively stable and economically favourable, especially in terms of favouring exports.

Conclusion. This study examined the impact of human agricultural and nonagricultural exports on infrastructural investment in Nigeria between the periods of 1980 2015. Secondary data were collected from the CBN statistical bulletin and World Bank. The dependent variables used was infrastructural investment (ROCY) while the explanatory variables used include agricultural export (AGEX), non-agricultural export (NAGEX), exchange rate (EXRT), labour force participation rate (LFPR) and inflation rate (INFL). The model was estimated using the Autoregressive Distributed Lag - Unrestricted Error Correction Model (ARDL-UECM). The regression result showed that agricultural export has a significant relationship with infrastructural investment while non-agricultural export was found to have an insignificant relationship with the explanatory variable. The study recommended that the government should invest in mechanised farming and as well ensure that the agricultural sector is made more viable and productive since we have comparative advantage in agriculture. It is also recommended that agricultural produce should not be exported in its primary form but there should be value added, in order to make Nigeria's exports more competitive in the international market. Finally, national income generated from agricultural and non-agricultural exports should be properly accounted for and invested into more capital projects to boost the level of infrastructure in the Nigerian economy. 


\section{References}

1. Central Bank of Nigeria. CBN Statistical Bulletin, Abuja, 2019.

2. Gilbert N. A., Linyong S. G., Divine G. M. Impact of Agricultural Export on Economic Growth in Cameroon: Case of Banana, Coffee and Cocoa. International Journal of Business and Management Review. 2013. №1(1). P.44-71.

3. Hyunsoo K. Agricultural Exports and Economic Growth: Empirical Evidence from the Major Rice Exporting Countries. Agricultural Economics (ZemědělskáEkonomika). 2015. N 61. P. 81-87.

4. Ijirshar, V. U. The Empirical Analysis of Agricultural Exports and Economic Growth in Nigeria. Journal of Development and Agricultural Economics. 2015. Vol. 7(3). P. 113-122. https://doi.org/10.5897/JDAE2014.0615.

5. Jouanjean M. Targeting Infrastructure Development to Foster Agricultural Trade and Market Integration in Developing Countries: An Analytical Review. 2013. URL https://www.odi.org/ publications/7580-infrastructure-development-agricultural-trademarket-integration.

6. Krugman P. R. Obstfeld M., Melitz M. J. International Economics: Theory and Policy (9th ed.). Boston, MA: Pearson, 2012.

7. Oluwatoyese O. P., Applanaidu S. D. and Abdulrazak N. Agricultural Export, Oil Export and Economic Growth in Nigeria: Multivariate Co-integration Approach. International Journal of Environnemental \& Agriculture Research. 2016. Vol. 2, Issue 2.

8. OPEC. OPEC Publications, 2020.

9. Orji A, Ogbuabor J. E, Anthony-Orji O. I., Alisigwe J. N. Agricultural Financing and Agricultural Output Growth in Developing Economies: Any Causal Linkage in Nigeria? International Journal of Finance, Insurance and Risk Management. 2020 Vol. 10, Issue 2. P. 34-43. https://doi.org/10.35808/ijfirm/213. URL: https://www.journalfirm.com/journal/213\#.

10. Orji A, Ogbuabor J. E., Okeke C. M., Anthony-Orji O. I. Exchange Rate Movements and the Agricultural Sector in Nigeria: An Empirical Investigation. Journal of Academic Research in Economics. 2019. Vol. 11(3). P. 616-627. URL: http://www.jare-sh.com/downloads/dec_2019/orji1.pdf.

11. Orji A., Ogbuabor J. E., Umesiobi S. Agricultural Outputs, Food Security and Economic Development: Some Policy Options and Strategies for Africa. European Journal of Social Sciences. 2014. Vol. 45(3). P. 305-318. URL: http://www.europeanjournalofsocialsciences.com/issues/EJSS_ 45_3.html.

12. Oyakhilomen O., Zibah G. R. Agricultural Production and Economic Growth in Nigeria: Implication of Rural Poverty Allocation. Quarterly Journal of International Agriculture. 2014. Vol. 53(3). P. 207-223.

13. World Bank. World Bank Publications, 2020

14. Pesaran M. H., Shin Y., Smith R. J. Bounds Testing Approaches to the Analysis of Level Relationships. Journal of Applied Economics. 2001. Vol. 16(3). P. 289-326. https://doi.org/10.1002/jae.616.

15. Verter N., Bečvařova V. The Impact of Agricultural Exports on Economic Growth in Nigeria. Acta Universitatis Agriculturaeet Silviculturae Mendelianae Brunensis. 2016. Vol. 64(2). P. 691-700. https://doi.org/10.11118/actaun201664020691.

\section{References}

1. Central Bank of Nigeria (2019) CBN Statistical Bulletin, Abuja.

2. Gilbert, N.A., Linyong, S. G., \& Divine, G. M. (2013). Impact of Agricultural Export on Economic Growth in Cameroon: Case of Banana, Coffee and Cocoa. International Journal of Business and Management Review, 1(1), 44-71.

3. Hyunsoo, K. (2015) Agricultural Exports and Economic Growth: Empirical Evidence from the Major Rice Exporting Countries. Agricultural Economics (ZemědělskáEkonomika), 61, 81-87.

4. Ijirshar, V. U. (2015). The Empirical Analysis of Agricultural Exports and Economic Growth in Nigeria. Journal of Development and Agricultural Economics, 7(3), 113-122. DOI: 10.5897/JDAE2014.0615.

5. Jouanjean, M. (2013). Targeting Infrastructure Development to Foster Agricultural Trade and Market Integration in Developing Countries: An Analytical Review. Retrieved from https://www.odi.org/publications/7580-infrastructuredevelopment-agricultural-trade-market-integration

6. Krugman, P. R. Obstfeld, M. \& Melitz, M. J. (2012). International Economics: Theory and Policy (9th ed.). Boston, MA: Pearson.

7. Oluwatoyese O P, Applanaidu S D and Abdulrazak N (2016). Agricultural Export, Oil Export and Economic Growth in Nigeria: Multivariate Co-integration Approach. International Journal of Environnemental \& Agriculture Research. Vol. 2, Issue 2. 2016

8. OPEC (2020) OPEC Publications

9. Orji, A, Ogbuabor, J. E, Anthony-Orji, O.I and Alisigwe, J. N (2020) "Agricultural Financing and Agricultural Output Growth in Developing Economies: Any Causal Linkage in Nigeria? International Journal of Finance, Insurance and Risk Management, Volume 10, Issue 2, 34-43, 2020. DOI: 10.35808/ijfirm/213. Available online: https://www.journalfirm.com/journal/213\#

10. Orji, A, Ogbuabor, J.E, Okeke, C.M., Anthony-Orji, O.I. (2019). "Exchange Rate Movements and the Agricultural Sector in Nigeria: An Empirical Investigation". Journal of Academic Research in Economics, 11(3), 616-627. Available online: http://www.jare-sh.com/downloads/dec 2019/orji1.pdf.

11. Orji, A., Ogbuabor, J.E., Umesiobi, S. (2014). Agricultural Outputs, Food Security and Economic Development: Some Policy Options and Strategies for Africa. European Journal of Social Sciences, 45(3), 305-318. Available at: http://www.europeanjournalofsocialsciences.com/issues/EJSS 45_3.html.

12. Oyakhilomen, O. \& Zibah, G. R. (2014). Agricultural Production and Economic Growth in Nigeria: Implication of Rural Poverty Allocation. Quarterly Journal of International Agriculture, 53(3), 207-223.

13. World Bank (2020) World Bank Publications

14. Pesaran, M. H., Shin, Y., \& Smith, R. J. (2001). Bounds Testing Approaches to the Analysis of Level Relationships. Journal of Applied Economics, 16(3), 289-326. DOI: 10.1002/jae.616

15. Verter, N. \& Bečvařova, V. (2016). The Impact of Agricultural Exports on Economic Growth in Nigeria. Acta Universitatis Agriculturaeet Silviculturae Mendelianae Brunensis, 64(2), 691-700. DOI: http://dx.doi.org/10.11118/ actaun201664020691.

Оніній І. Антоні-Орджі, Антоні Орджі, Джонатан Е. Огбуабор, Прешез Езеаліго. Оцінки впливу сільськогосподарського та несільськогосподарського експорту на інфраструктурні інвестиції в Нігерії

Мета статmі - охарактеризувати вплив сільськогосподарського та несільськогосподарського експорту на інфраструктурні інвестиції в Нігерії.

Методика дослідження. У процесі дослідження використана модель авторегресії з розподіленим лагом - необмежена модель корекції помилок (ARDL-UECM) - для оцінки впливу сільськогосподарського та несільськогосподарського експорту на інфраструктурні інвестиції Нігерії. Модель ARDL була оцінена за допомогою Eviews 9.

Результати дослідження. Сільськогосподарський експорт має суттєве позитивне відношення до інфраструктурних інвестицій, тоді як несільськогосподарський експорт - незначну залежність від пояснювальної змінної.

Елементи наукової новизни. Виконане дослідження доповнює основні літературні джерела з окресленого питання для економіки Нігерії та інших суміжних економік, адже це перша праця, в якій аналізується спільний вплив сільськогосподарського та несільськогосподарського експорту на інфраструктурні інвестиції в Нігерії. Наведено деякі інноваційні висновки та рекомендації, згідно з якими уряду варто більше інвестувати в механізоване сільське господарство, а також забезпечити сільськогосподарському сектору більшу життєздатність та продуктивність, оскільки країна має порівняльні переваги у сільському господарстві.

Практична значущість. У результаті емпіричних досліджень підтверджено, що сільськогосподарська продукція повинна не тільки експортуватись у вигляді сировини, а й мати додану вартість, щоб перетворити експорт Нігерії на конкурентоспроможніший на міжнародному ринку. Доходи, отримані урядом від сільськогосподарського та несільськогоспо- 
дарського експорту повинні бути відповідним чином враховані та інвестовані у більше капітальних проєктів для підвищення рівня інфраструктури нігерійської економіки. Табл.: 4. Рис.: 2 . Бібліогр.: 15.

Ключові слова: аналіз; сільське господарство; сільськогосподарський і несільськогосподарський експорт; інфраструктура; інвестиції.

Оніній І. Антоні-Орджі - доктор філософії, відділ економіки, Університет Нігерії, Нсукка (Postal code 410001 Nsukka, Enugu, Nigeria)

E-mail: onyinye.anthony-orji@unn.edu.ng

ORCID iD http://orcid.org/0000-0002-0603-7264

Антоні Орджі - доктор філософії, відділ економіки, Університет Нігерії, Нсукка (Postal code 410001 Nsukka, Enugu, Nigeria)

E-mail: anthony.orji@unn.edu.ng

ORCID iD http://orcid.org/0000-0003-4032-7051

Джонатан Е. Огбуабор - доктор філософії, відділ економіки, Університет Нігерії, Нсукка (Postal code 410001 Nsukka, Enugu, Nigeria)

E-mail: jonathan.ogbuabor@unn.edu.ng

ORCID iD http://orcid.org/0000-0002-0162-0303

Прешез Езеаліго - Університет Нігерії, Нсукка (Postal code 410001 Nsukka, Enugu, Nigeria)

E-mail: precious.ezealigo.189171@unn.edu.ng

Ониний И. Антони-Орджи, Антони Орджи, Джонатан Е. Огбуабор, Прешез Езеалиго. Оценки влияния сельскохозяйственного и несельскохозяйственного экспорта на инфраструктурные инвестиции в Нигерии

Цель статьи - охарактеризовать влияние сельскохозяйственного и несельскохозяйственного экспорта на инфраструктурные инвестиции в Нигерии.

Методика исследования. В процессе исследования использована модель авторегрессии с распределённым лагом - модель неограниченной коррекции ошибок (ARDL-UECM) - для оценки влияния сельскохозяйственного и несельскохозяйственного экспорта на инфраструктурные инвестиции Нигерии. Модель ARDL была оценена с помощью Eviews 9.

Результаты исследования. Сельскохозяйственный экспорт имеет существенное положительное отношение к инфраструктурным инвестициям, тогда как несельскохозяйственный экспорт - незначительную зависимость от пояснительной переменной.

Элементы научной новизны. Выполненное исследование дополняет основные литературные источники по определенному вопросу для экономики Нигерии и других смежных экономик, ведь это первая работа, в которой анализируется совместное влияние сельскохозяйственного и несельскохозяйственного экспорта на инфраструктурные инвестиции в Нигерии. Приведены некоторые инновационные выводы и рекомендации, согласно которым правительству следует больше инвестировать в механизированное сельское хозяйство, а также обеспечить сельскохозяйственному сектору большую жизнеспособность и продуктивность, поскольку страна имеет сравнительные преимущества в сельском хозяйстве.

Практическая значимость. В результате эмпирических исследований подтвердилось, что сельскохозяйственная продукция должна не только экспортироваться в виде сырья, но и иметь добавленную стоимость, чтобы превратить экспорт Нигерии на более конкурентоспособный на международном рынке. Доходы, полученные правительством от сельскохозяйственного и несельскохозяйственного экспорта должны быть соответствующим образом учтены и инвестированы в больше капитальных проектов для повышения уровня инфраструктуры нигерийской экономики. Табл.: 4. Илл.: 2. Библиогр.: 15.

Ключевые слова: анализ; сельское хозяйство; сельскохозяйственный и несельскохозяйственный экспорт; инфраструктура; инвестиции.

Ониний И. Антони-Орджи - доктор философии, отдел экономики, Университет Нигерии, Hcyкка (Postal code 410001 Nsukka, Enugu, Nigeria)

E-mail: onyinye.anthony-orji@unn.edu.ng

ORCID iD http://orcid.org/0000-0002-0603-7264

Антони Орджи - доктор философии, отдел экономики, Университет Нигерии, Нсукка (Postal code 410001 Nsukka, Enugu, Nigeria)

E-mail: anthony.orji@unn.edu.ng

ORCID iD http://orcid.org/0000-0003-4032-7051

Джонатан Е. Огбуабор - доктор философии, отдел экономики, Университет Нигерии, Нсукка (Postal code 410001 Nsukka, Enugu, Nigeria)

E-mail: jonathan.ogbuabor@unn.edu.ng

ORCID iD http://orcid.org/0000-0002-0162-0303

Прешез Езеалиго - Университет Нигерии, Нсукка (Postal code 410001 Nsukka, Enugu, Nigeria)

E-mail: precious.ezealigo.189171@unn.edu.ng

The article has been received 06.05.2020

Revision: 16.05 .2020

Бібліографічний опис для цитування:

Onyinye I. Anthony-Orji, Anthony Orji, Jonathan E. Ogbuabor, Precious Ezealigo. Empirical analysis of agricultural and non-agricultural exports' impact on infrastructural investment in Nigeria. Економіка АПК. 2020. № 5. C. 87 - 96. https://doi.org/10.32317/2221-1055.202005087

Onyinye I. Anthony-Orji, Anthony Orji, Jonathan E. Ogbuabor \& Precious Ezealigo (2020). Empirical analysis of agricultural and non-agricultural exports' impact on infrastructural investment in Nigeria. Ekonomika APK, 5, pp. 87 - 96 [In English]. https://doi.org/10.32317/2221-1055.202005087 